\title{
ANALISIS PENERIMAAN PENGGUNA SISTEM INFORMASI AKADEMIK, STUDI KASUS STIKES HARAPAN BANGSA
}

\author{
Iis Setiawan Mangku Negara ${ }^{1}$ \\ Fania Mutiara Savitri ${ }^{2}$
}

\author{
${ }^{1}$ Universitas Harapan Bangsa, Purwokerto, Indonesia \\ ${ }^{2}$ Universitas Islam Negeri Walisongo, Semarang, Indonesia
}

Diterima: Mei 2019, Disetujui: Juni 2019, Dipublikasikan: Juli 2019

\begin{abstract}
Information systems and technology develops very rapidly and have significant impact on all areas. The information technology not only to use in the business sector, but also the public sector, one of which is an higher education institutions. The efficiency and effectiveness of process information using information systems will only occur if the technology is received by individuals in the organization. This Study is a research which discusses factors that affecting lecturers, students, and stafts acceptance of academic information systems. 200 respondens was participated in this study. Technolgy Acceptance Model was used as adoption model. In addition to testing the variables, this study also examined whether TAM theory can be used to determine user acceptance SIAK-SHB in STIKes Harapan Bangsa. Data analysis was performed with the approach of Structural Equation Modeling. Based on the results we concluded that the Actual System Use is influenced by behavioral intention to use. Behavioral Intention to Use is influenced by Perceived Usefulness and Perceived Usefulness is influenced by Perceived Easy of Use.
\end{abstract}

Keywords: Technology Acceptance Model, Structural Equation Modeling, Academic Information System User Acceptance

\begin{abstract}
ABSTRAK
Sistem informasi dan Teknologi informasi berkembang dengan sangat pesat dan berdampak signifikan terhadap segala bidang. Pemanfaatan teknologi informasi tidak hanya pada pemanfaatan sektor bisnis, tetapi juga sektor publik yang salah satunya adalah lembaga perguruan tinggi. Efisiensi dan efektifitas proses informasi dengan menggunakan sistem informasi hanya akan terjadi apabila teknologi tersebut diterima oleh individu dalam organisasi. Tesis ini merupakan hasil riset yang akan membahas mengetahui faktor - faktor apa yang sajakah yang mempengaruhi penerimaan dosen, mahasiswa dan staf akademik dalam menggunakan Sistem Informasi Akademik STIKes Harapan Bangsa. Sejumlah 200 responden ikut berpartisipasi dalam penelitian ini. Adapun model adopsi teknologi yang digunakan adalah model Technolgy Acceptance Model. Selain menguji variabel, penelitian ini juga menguji apakah teori TAM dapat digunakan untuk mengetahui penerimaan pengguna SIAK-SHB di Stikes Harapan Bangsa. Analisis data dilakukan dengan pendekatan Structural Equation
\end{abstract}


Modeling. Berdasarkan hasil dari analisis diperoleh kesimpulan bahwa Actual System Use dipengaruhi oleh Behavioral Intention to Use, Behavioral Intention to Use dipengaruhi oleh Perceived Usefulness dan Perceived Usefulness dipengaruhi oleh Perceived Easy of Use.

Kata Kunci :Technolgy Acceptance Model, Structural Equation Modeling, Penerimaan Pengguna Sistem Informasi Akademik

\section{PENDAHULUAN}

Sistem informasi dan Teknologi informasi berkembang dengan sangat pesat dan berdampak signifikan terhadap segala bidang. Dengan semakin kompleknya kegiatan bisnis dan operasional organisasi dan didukung oleh perkembangan sistem informasi dan teknologi informasi yang semakin cepat menuntut organisasi untuk merencanakan dan mengembangkan suatu sistem yang dapat membantu kegiatan operasionalnya dengan efektif dan efisien.

Pemanfaatan teknologi informasi tidak hanya pada pemanfaatan sektor bisnis, tetapi juga sektor publik yang bersifat pelayanan kepada masyarakat. Salah satu sektor publik yang memanfaatkan teknologi sistem informasi adalah lembaga perguruan tinggi. Bagi lembaga perguruan tinggi, teknologi sistem informasi sangat dibutuhkan untuk menunjang proses pengajaran. Diharapkan dengan pemanfaatan sistem informasi dapat meningkatkan produktifitas dan efisiensi kerja dari pihak manajemen.

Teknologi informasi dapat didefinisikan sebagai perpaduan antara teknologi komputer dan juga telekomunikasi dengan sistem yang lain seperti perangkat keras, perangkat lunak, database, teknologi jaringan, dan peralatan teknologi lainnya (Maharsi,2004). Pemakaian teknologi informasi paling banyak digunakan pada transaksi ekonomi dan bisnis yang dilakukan pada perusahaan sehingga tidak lagi dilakukan dengan kertas (paperless) seperti electronic fund transfer, electronic data interchange, electronic commerce. Di era tahun 1990, teknologi informasi merupakan sumber daya keempat setelah sumber daya manusia, uang dan mesin yang digunakan manajer untuk membentuk dan mengendalikan perusahaan (Rokart dalam Kurniawan, 2008).

Stikes Harapan Bangsa Purwokerto adalah sebuah institusi pendidikan yang memberikan pendidikan kesehatan setingkat DIII dan S1. Kebutuhan untuk sistem informasi yang dapat membantu kegiatan operasionalnya terutama di 
bidang akademik dirasakan sangat penting untuk diterapkan di institusi tersebut, sehingga pada tahun 2010 Stikes Harapan Bangsa Purwokerto menerapkan Sistem Informasi Akademik. Sistem Informasi Akademik Stikes Harapan Bangsa (SIAKSHB) merupakan sistem informasi berbasis web yang dapat di akses melalui portal http://shb.ac.id.

Dengan diterapkannya Sistem Informasi Akademik ternyata memberikan reaksi dari para civitas akademis di Stikes Harapan Bangsa, baik reaksi positif maupun reaksi negatif terhadap sistem informasi tersebut.Pada penerapan SIAK SHB, terlihat indikasi rendahnya penerimaan pengguna (user acceptance) terhadap SIAK SHB.

Berdasarkan studi pendahuluan yang sudah penulis lakukan terdapat beberapa kendala antara lain $30 \%$ dosen terlambat dalam menginputkan nilai sesuai jadwal yang telah ditentukan, $22 \%$ dosen yang masih belum memanfaatkan secara maksimal fungsi dari sistem informasi, salah satunya terlihat dari masih adanya tempelan daftar nilai di jendela ruang dosen, $43 \%$ jadwal perkuliahan belum diinputkan oleh bagian program studi padahal sudah melewati batas waktu yang telah ditetapkan, 30\% dosen mengatakan bahwa dengan SIAK SHB malah semakin repot dan menyatakan tidak perlu adanya SIAK SHB, Terdapat 96 alert perwalian yang tampil pada modul manajemen dikarenakan dosen perwalian yang belum melakukan pembinaan kepada mahasiswa bimbingannya.

Empat semester sejak diterapkannya SIAK SHB masih terdapat keterlambatan mahasiswa dalam melakukan pengisian KRS yang bukan disebabkan karena keterlambatan dalam melakukan pembayaran. Data terakhir pada tahun ajaran 2012/2013 terdapat 54 mahasiswa Program Studi D3 Kebidanan yang terlambat dalam pengisian rencana studi, 76 mahasiswa Program Studi D3 Keperawatan dan 31 mahasiswa Program Studi S1 Keperawatan. Alasan utama keterlambatan melakukan isian KRS adalah sedang melakukan praktek diluar sehingga tidak sempat mengakses SIAK melalui internet. Melihat hal tersebut pola penerimaan individu terhadap sistem informasi yang diterapkan perlu diketahui. Dalam penelitian ini dilakukan kajian tentang penerimaan pengguna sistem informasi akademik di STIKes Harapan Bangsa ( SIAK SHB ) dengan menggunakan model TAM, Technology Acceptance Model. Adapun 
permasalahan yang diangkat dalam penelitian ini adalah faktor - faktor apa saja yang mempengaruhi penerimaan pengguna terhadap SIAK SHB. Kemudian apakah faktor persepsi tentang kegunaan, persepsi tentang kemudahan penggunaan, sikap pengguna, niat untuk menggunakan dan penerimaan pengguna mempengaruhi penerimaan pengguna terhadap SIAK SHB.

\section{TINJAUAN PUSTAKA}

\section{Sistem Informasi Akademik}

Jogiyanto (2000) menyebutkan bahwa sistem informasi adalah suatu kegiatan dari prosedur-prosedur yang diorganisasikan, bilamana dieksekusi akan menyediakan informasi untuk mendukung pengambilan keputusan dan pengendalian di dalam organisasi. Sistem informasi berbasis komputer merupakan suatu rangkaian perangkat keras dan perangkat lunak yang dirancang untuk mentransfer data menjadi informasi yang berguna.Setiap organisasi yang menggunakan komputer untuk memproses data transaksi memiliki fungsi sistem informasi.Fungsi sistem informasi bertanggung jawab atas pemrosesan data.

Sistem informasi akademik merupakan sistem yang dapat memberikan informasi-informasi yang berkaitan dengan hal-hal di bidang akademik, misalkan informasi nilai tiap-tiap mata kuliah, jadwal perkuliahan, dan lain - lain. Sistem informasi akademik juga bisa digunakan dalam bidang pendidikan baik di lembaga-lembaga formal maupun lembaga-lembaga nonformal dimana aktifitas administrasinya tidak jauh dari kegiatan-kegiatan administrasi kantor-kantor lain sehingga jika diklasifikasikan, sistem informasi akademik juga digolongkan sebagai sistem informasi manajemen tapi dalam lingkup yang kecil, karena tidak seluruh kegiatan sistem informasi manajemen dilakukan di sini, namun lebih mengarah pada kegiatan pengolahan data (Jogiyanto,2000).

Sistem Informasi Akademik merupakan sumber daya dalam bentuk informasi yang ada kaitannya dengan masalah-masalah akademik di kampus. Sistem Informasi Akademik selain merupakan sumber daya informasi di kampus, juga dapat digunakan sebagai sarana media komunikasi antara dosen dan mahasiswa, mahasiswa dengan mahasiswa, dosen dengan pejabat kampus terkait 
dan siapa saja yang ada di lingkungan kampus tersebut. Karena menggunakan teknologi internet tidak hanya dilakukan dalam kampus saja tetapi diluar kampuspun bias dilakukan bahkan dimana saja di seluruh dunia ini asalkan ada sebuah komputer yang terhubung dengan internet(Arifin, 2002).

Sistem informasi akademik mampu memberikan berbagai informasi yang berhubungan dengan kegiatan belajar mengajar di kampus, dimana informasi tersebut dihasilkan dari semua data yang diperolah dalam kegiatan administratif di sekolah. Sistem informasi akademik dapat mengurangi resiko dengan menggunakan cara manual. Dimana pada sistem manual dengan media penyimpanan yang masih berupa kertas memiliki banyak resiko yang menyebabkan terjadinya kehilangan data ataupun data yang tidak update. Sebagai contoh jenis informasi yang ada di STIKes Harapan Bangsa adalah :

a. Berita, berisi informasi terbaru yang diterbitkan oleh lembaga pendidikan maupun informasi teknologi dari berbagai sumber berita.

b. Pendidikan, berisi informasi yang berkaitan dengan perkuliahan yang terdapat dilembaga pendidikan, misalnya kurikulum, Rencana Pelaksanaan Perkuliahan (RPP), dosen, materi kuliah, tugas akhir dan penelitian.

c. Data Personal, berisi Informasi yang berrhubungan dengan mahasiswa diantaranya;

1) Kartu Rencana Studi (KRS) sesuai dengan mata kuliah yang telah diprogramkan dalam satu semester

2) Kartu Hasil Studi (KHS) untuk mengetahui hasil yang telah dicapai selama mengikuti perkuliahan dan hasil evaluasi studi, sekaligus mengetahui indeks prestasinya

d. Jadwal Perkuliahan, yang berisi tentang jadwal kuliah, kegiatan mahasiswa, memonitor jadwal perkuliahan dosen, jumlah kehadiran dalam mengikuti perkuliahan

e. Electronic Mail (Email), fasilitas ini untuk mengirim dan menerima surat/pesan sekaligus dapat dijadikan sebagai sarana atau alat diskusi antar mahasiswa, dosen bahkan karyawan dalam lembaga pendidikan.

\section{Tecnology Acceptance Models}


Technologi Acceptance Model (TAM) diperkenalkan oleh Fred D. Davis pada tahun 1989, digunakan untuk memprediksi penerimaan pengguna terhadap penggunaan teknologi baru. Model TAM merupakan adopsi dari model TRA (Theory of Reasoned Action) yang dikembangkan oleh Martin Fishbein dan Icek Ajzen pada tahun 1975 untuk bidang Sistem Informasi yang merupakan teori tindakan yang berlandaskan dengan satu asumsi bahwa reaksi dan persepsi seseorang terhadap sesuatu hal akan menentukan sikap dan perilaku orang tersebut. Tujuan utama TAM untuk memberikan dasar penelusuran pengaruh faktor luar terhadap kepercayaan, sikap dan tujuan pengguna. Model TAM mengemukakan bahwa manfaat yang dirasakan (usefulness) dan kemudahan penggunaan (easy of use) yang dirasakan oleh pengguna menentukan niat individu untuk menggunakan sistem tersebut, sehingga evaluasi terhadap kegunaan teknologi tersebut merupakan kunci utama agar pengguna bisa secara maksimal menggunakan teknologi itu sendiri.Davis (1989) menambahkan, TAM merupakan perbaikan dari model TRA (Theory of Reasoned Action), TAM mengadopsi komponen tetap dari model TRA umumnya dan menerapkannya komponenkomponen tersebut sebagai domain khusus dari teknologi komputer dan yang lainnya untuk teknologi informasi. Namun yang membedakan keduanya (TRA dan TAM) adalah penempatan faktor-faktor sikap dari TRA, dimana TAM memperkenalkan dua variabel kunci, yaitu perceived ease of use dan perceived usefulness, yang memiliki relevancy pusat untuk memprediksikan sikap penerimaan pengguna terhadap teknologi komputer. Model TAM secara khusus dikembangkan untuk menjelaskan penerimaan individu terhadap teknologi komputer pada latar organisasi (organizational setting). Model TAM berakar dari The T'heory of Reactioned Actioned (TRA) yang dikembangkan Fisbhein dan Azjentahun 1975 (Fichman, 1992; Schillawaert, et. al.,2001). Secara garis besar, TRA menyatakan bahwa perilaku (behavior) individu dapat diprediksi dari minat berperilaku (behavior intention). Adapun minat berperilaku individu dipengaruhi oleh dua faktor, yaitu sikap terhadap perilaku (attitude toward behavior) dan norma subyektif (subjective norms).

Dengan demikian, secara sederhana TRA menyatakan bahwa seseorang akan melakukan suatu perbuatan apabila ia memandang perbuatan tersebut positif 
dan bila ia percaya bahwa orang lain ingin agar ia melakukannya. Semakin positif sikap dan norma subyektif seseorang atas perilaku tertentu, maka kecenderungan minat dan perilaku aktualnya juga semakin kuat.

Menurut Davis F.D (1989) dalam teori Technology Acceptance Model (TAM) dijelaskan bahwa persepsi pengguna akan menentukan sikapnya dalam kemanfaatan penggunaan TI. Dalam TAM digambarkan bahwa penerimaan penggunaan TI dipengaruhi oleh kemanfaatan (usefulness) dan kemudahan penggunaan (ease of use). Kemanfaatan dan kemudahan penggunaan mempunyai pengaruh ke minat perilaku. Pemakai teknologi akan mempunyai minat menggunakan teknologi (minat perilaku) jika merasa sistem teknologi bermanfaat dan mudah digunakan. Pemakai sistem informasi akan lebih banyak memanfaatkan sistem jika sistem informasi tersebut mudah digunakan. Sebaliknya jika sistem informasi tidak mudah digunakan maka pemakai akan lebih sedikit dalam memanfaatkan sistem informasi tersebut.

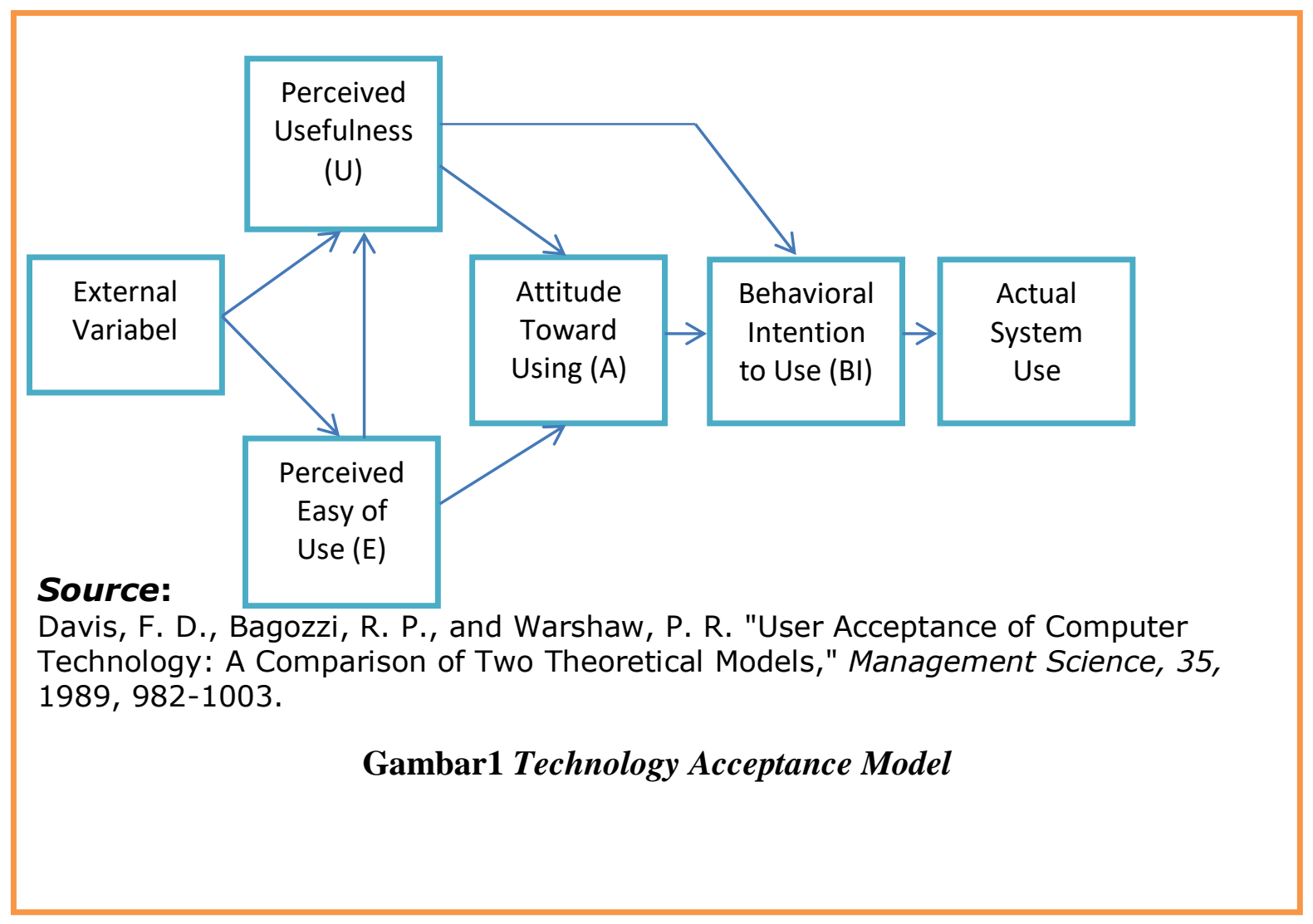




\section{Perceived Ease of Use}

Persepsi pengguna terhadap kemudahan (perceived ease of use) didefinisikan sebagai sejauhmana seseorang percaya bahwa menggunakan suatu teknologi akan bebas dari usaha (Jogiyanto, 2008). Berdasarkan definisi diatas dapat disimpulkan bahwa kemudahan penggunaan akan mengurangi usaha baik waktu dan tenaga seseorang dalam mempelajari teknologi informasi. Pengguna TI mempercayai bahwa TI yang lebih fleksibel, mudah dipahami dan mudah pengoperasiannya sebagai karakteristik kemudahan penggunaan. Davis F.D (1989) memberikan indikator kemudahan penggunaan TI yaitu mudah dipelajari, bisa mengerjakan dengan mudah apa yang diinginkan pengguna, ketrampilan pengguna bertambah, mudah dioperasikan. Berdasarkan beberapa definisi tersebut, dapat dikatakan bahwa kemudahan penggunaan mampu mengurangi usaha seseorang baik waktu maupun tenaga untuk mempelajari system atau teknologi karena individu yakin bahwa system atau teknologi tersebut mudah untuk dipahami. Intensitas penggunaan dan interaksi antara pengguna (user) dengan sistem juga dapat menunjukkan kemudahan penggunaan. Sistem yang lebih sering digunakan menunjukkan bahwa system tersebut lebih dikenal, lebih mudah dioperasikan dan lebih mudah digunakan oleh penggunanya (Davis F.D, 1989).

Penelitian sebelumnya menunjukan bahwa konstruk kemudahan penggunaan mempengaruhi sikap (attitude), minat (behavioral intention) dan penggunaan sesungguhnya (actual usage).

\section{Perceived Usefulness}

Jogiyanto (2008) mendefinisikan persepsi pengguna terhadap kegunaan (perceived usefulness) sebagai sejauhmana seseorang percaya bahwa menggunakan suatu teknologi akan meningkatkan kinerja pekerjaannya, sedangkan Adamson dan Shine (2003) mendefinisikan Persepsi Kebermanfaatan sebagai konstruk kepercayaan seseorang bahwa penggunaan sebuah teknologi tertentu akan mampu meningkatkan kinerja mereka. Dari dua definisi tersebut dapat disimpulkan bahwa Persepsi Kebermanfaatan system berkaitan dengan produktifitas dan efektifitas system dari kegunaan 
dalam tugas secara menyeluruh untuk meningkatkan kinerja orang yang menggunakan system tersebut. Kemanfaatan penggunaan TI dapat diketahui dari kepercayaan pengguna TI dalam memutuskan penerimaan TI, dengan satu kepercayaan bahwa penggunaan TI tersebut memberikan konstribusi positif bagi penggunanya. Pengukuran konstruk kegunaan menurut Davis F.D (1989) yaitu menjadikan pekerjaan lebih cepat (work more quickly), bermanfaat (usefull), menambah produktifitas (increase productivity), mempertinggi efektifitas (enhanced efectiveness) dan mengembangkan kinerja pekerjaan (improve job performance).

Penelitian ini berusaha menguji pengaruh faktor-faktor motivasional terhadap intensi keperilakuan (behavioral intention) kelanjutan penggunaan teknologi informasi. Secara khusus, penelitian ini mencoba melihat dampak faktor-faktor motivasional tersebut terhadap penggunaan komputer. Penelitian lainnyamenunjukan bahwa konstruk persepsi pengguna terhadap kegunaan mempengaruhi secara positif dan signifikan terhadap penggunaan sistem informasi.Selain itu konstruk perceived usefulness merupakan konstruk yang paling signifikan dan penting dalam mempengaruhi sikap (attitude), minat (behavioral intention) didalam menggunakan teknologi informasi dibandingkan konstruk lainnya.

\section{Attitude Toward Using}

Attitude Toward Using dalam TAM dikonsepkan sebagai sikap terhadap penggunaan sistem yang berbentuk penerimaan atau penolakan sebagai dampak bila seseorang menggunakan suatu teknologi dalam pekerjaannya. Peneliti lain menyatakan bahwa faktor sikap (attitude) sebagai salah satu aspek yang mempengaruhi perilaku individual. Sikap seseorang terdiri atas unsur kognitif/cara pandang (cognitive), afektif (affective), dan komponenkomponen yang berkaitan dengan perilaku (behavioral components 


\section{Behavior Intention to Use}

Triandis dalam Sunarta (2005) mengemukakan bahwa perilaku seseorang merupakan ekspresi dari keinginan atau minat seseorang (intention), dimana keinginan tersebut dipengaruhi oleh faktor-faktor sosial, perasaan (affect), dan konsekuensi-konsekuensi yang dirasakan. Davis F.D (1989) mengemukakan bahwa adanya manfaat yang dirasakan oleh pemakai TI akan meningkatkan minat mereka untuk menggunakan TI. Sedangkan Goodhue et.al., (1995) menyatakan bahwa keyakinan seseorang akan kegunaan TI akan meningkatkan minat mereka dan pada akhirnya individu tersebut akan menggunakan TI dalam pekerjaannya.

Menurut Venkatesh, V. And Bala, H (2008), dinyatakan bahwa ditinjau dari proses psikologis, beliefs seseorang terhadap teknologi informasi yang meliputi belief yang terkait dengan usefulness dan ease of use dipengaruhi oleh tiga sumber pengaruh dominan, yaitu: pengaruh institusi ( institutional influences), pengaruh sosial (social influences) serta factor individu (individual factors). Para peneliti dibidang system informasi telah menyarankan digunakannya model niat (intention model) dari psikologi social sebagai dasar teori potensial dalam melakukan riset tentang penentu perilaku pengguna (user behavior) ( Swanson, 1982; Christie,1981, dalam Davis, Bagozzi, dan Warshaw, 1989). Berdasarkan pendekatan behavioral intention approach, keputusan seseorang untuk menerima teknologi informasi merupakan tindakan sadar yang bisadijelaskan dan diprediksikan melalui niat perilaku (behavioral intentions).

\section{Actual System Use}

Actual System Usage yaitu kondisi nyata penggunaan sistem yang dikonsepkan dalam bentuk pengukuran terhadap frekuensi dan durasi waktu penggunaan teknologi (Iqbaria.et.al, 1997). Penelitian sebelumnya menyebutkan bahwa secara individu maupun kolektif penerimaan penggunaan dapat dijelaskan dari variasi penggunaan suatu sistem, karena diyakini penggunaan suatu sistem yang berbasis TI dapat mengembangkan kinerja individu atau kinerja organisasi.Secara umum diketahui bahwa 
penerimaan TI dilihat dari penggunaan sistem, frekuensi penggunaan komputer dan dapat juga dilihat dari aspek kepuasan pengguna.Dalam Iqbaria.et.al (1997) menjadikan penggunaan sistem sebagai indikator utama penerimaan pengguna.

\section{Organizational Factor}

Meningkatnya tuntutan organisasi akan efisiensi dan efektivitas pekerjaan akan mendorong setiap individu untuk lebih dapat bekerja cepat, mampu bersaing, dan mampu mengatasi tantangan dalam pekerjaannya. Setiap individu yang ditempatkan pada konidisi-kondisi lingkungan yang sama mungkin menunjukkan tanggapan psikologis, fisik, dan perilaku yang sangat berbeda. Oleh karena itu, stres dapat mempengaruhi seseorang dengan berbagai cara yang berbeda dan dengan akibat yang bermacammacam tergantung kondisi individu yang bersangkutan serta sumber potensial tekanan kerja tertentu yang dievaluasi, yang mungkin menjadi penyebab stres bagi seseorang tetapi tidak bagi orang lain. Salah satu penghambat kinerja karyawan adalah stres. Sumber stres dari pengaruh lingkungan tehnologi

Menurut Kurniawan (2008) faktor-faktor organisasi meliputi 2 yaitu:

a) Faktor internal adalah segala keseluruhan faktor yang ada di dalam organisasi dimana factor tersebut dapat mempengaruhi organisasi dan kegiatan organisasi. Adalah penyebab perubahan yang berasal dari dalam organisasi yang bersangkutan, yang dapat berasal dari berbagai sumber.Contoh Faktor Internal :

a. Perubahan kebijakan lingkungan

b. Perubahan Tujuan

c. Perluasan Wilayah operasi tujuan

d. Volume kegiatan bertambah banyak

e. Sikap dan perilaku dari para anggota organisasi

b) Faktor eksternal adalah segala keseluruhan faktor yang ada di luar organisasi yang dapat mempengaruhi organisasi dan kegiatan organisasi. Beberapa factor tersebut antara lain : Politik, Hukum , Kebudayaan, Teknologi, Sumber alam, Demografi dan organisasi. Organisasi identic 
dengan individu ataupun sekelompok individu yang terstruktur dan sistematis yang tergabung dalam suatu system. Pengertian organisasi adalah wadah untuk sekelompok individu untuk berinteraksi dalam wewenang tertentu. Organisasi yang dibentuk terdiri dari berbagai kelompok yang memiliki kepentinga bersama untuk mencapai tujuan tertentu secara bersama.Siapapun memerlukan pengalaman dalam organisasi, ini dikarenakan manusia adalah makhluk social yang pastiakan berinteraksi dengan yang lain.

\section{Computer Self-Efficacy}

Istilah Computerself efficacy merupakan suatu konstrak penting dalam psikologi yang banyak digunakan para peneliti yang dikaitkan dengan variabel-variabel lain. Dalam penelitian Maharsi (2004) misalnya, Computerself efficacy mempengaruhi minat nasabah dalam menggunakan Internet Banking. Dalam riset bidang system informasi, banyak peneliti (Manon Bertrand and Stepahne Bouchard 2008; Michael Reid 2008) yang telah menguji variable self efficacy yang dihubungkan dengan berbagai perilaku komputer.

Computer Self Efficacy (CSE) didefinisikan oleh Compeau dan Higgins (1995) dalam Maharsi (2004) sebagai penilaian kapabilitas dan keahlian computer seseorang untuk melakukan tugas-tugas yang berhubungan dengan teknologi informasi. Sri Maharsi (2004) secara sederhana mendifinisikan CSE sebagai kemampuan seseorang dalam menggunakan komputer. Dari beberapa definisi CSE di atas, dapat ditarik kesimpulan bahwa CSE merupakan penilaian individu terhadap kemampuan diri untuk melaksanakan tugas-tugas komputasi dengan baik.

\section{SEM (Structural Equation Modeling)}

Structural Equation Modeling merupakan teknik analisis statistik multivariat yang merupakan kombinasi dari teknik analisis faktor dan analisis regresi. SEM bertujuan untuk menguji hubungan - hubungan antar variabel yang ada pada suatu model. Sebelum dikembangkan program aplikasi komputer 
sebagai alat analisis SEM, pengguna SEM masih terbatas karena kompleksitas perhitungan matematis yang dimilikinya. SEM yang menggunakan program aplikasi AMOS, LISREL, EQS, dll, dalam analisis datanya disebut dengan istilah covariance based SEM karena menggunakan input berupa matriks kovarian. Covariance based SEM digunakan untuk menguji sebuah teori, bukan untuk membuat teori baru. Teori tersebut direpresentasikan sebagai suatu model yang akan diuji apakah model tersebut diterima atau ditolak. Karena pada dasarnya SEM merupakan kombinasi dari analisis faktor dan analisis regresi, maka pada pengujian model dengan pendekatan SEM, dilakukan dua tahapan pengujian berikut :

a. Pengujian terhadap measurement model

Measurement model adalah bagian dari model SEM yang menggambarkan hubungan antara variabel laten (variabel penelitian/konstruk unobserved variable) dengan indikator - indikatornya (alat ukur konstruk/variabel manifes/observed variable). Pengujian terhadap measurement model bertujuan untuk mengukur seberapa tepat indikator - indikator yang digunakan dalam mengukur variabel laten yang diukurnya.

b. Pengujian terhadapstructural model

Structural model adalah bagian dari model SEM yang menggambarkan hubungan antara variabel - variabel yang ada pada model tersebut. Pengujian terhadap structural modelbertujuan untuk mengetahui hubungan apakah yang ada pada variabel - variabel yang membangun model. 


\section{METODOLOGI}

Dalam penelitian ini, konstruk yang akan digunakan adalah External variabel, Perceived Ease of Use, Perceived Usefulness, Attitude Toward Using, Behavioral Intention to Use dan Actual System Use.

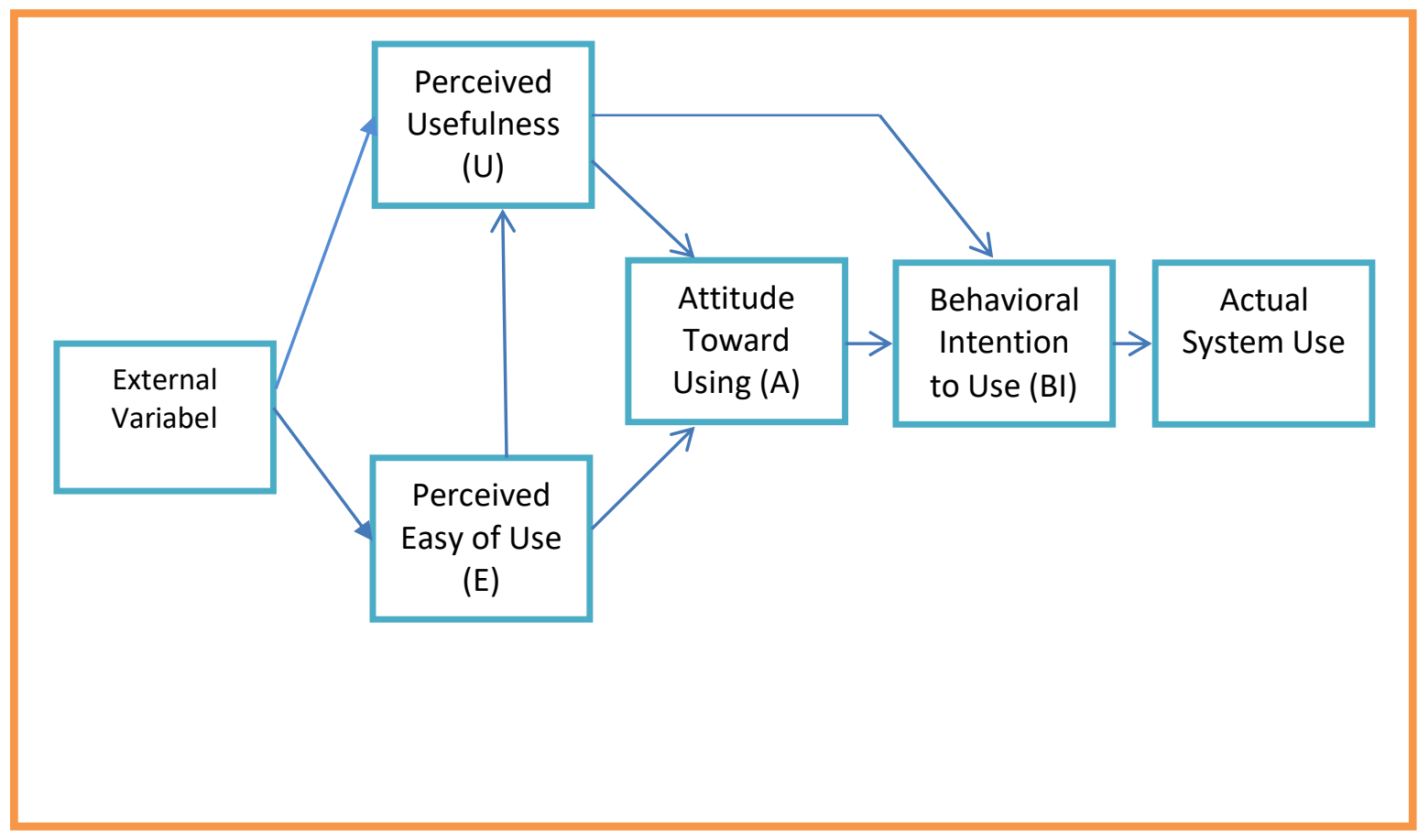

\section{Gambar 2Technology Acceptance Model}

Penelitian yang dilakukan merupakan penelitian kuantitatif dengan menggunakan pendekatan survei. Pendekatan survei ini dilakukan dengan melakukan penyebaran kuesioner pada sampel. Kuesiner tersebut disusun berdasarkan model TAM yang digunakan dalam penelitian ini. Data hasil dari kuesioner selanjutkan akan dianalisis dengan menggunakan teknik pemodelan statistik SEM dengan alat bantu software AMOS.

Populasi dalam penelitian ini adalah semua pengguna SIAK - SHB di Sekolah Tinggi Ilmu Kesehatan Harapan Bangsa yang terdiri dari mahasiswa, dosen dan karyawan administrasi. Jumlah mahasiswa pengguna SIAK - SHB berjumlah 1.312 orang, dosen 43 orang dan karyawan administrasi 13 orang, sehingga jumlah keseluruhan populasi sebanyak 1.368 orang. Pada penelitian ini jumlah sampel yang penulis ambil sebesar 200 sampel dengan teknik Purposive Sampling. Hal ini dilakukan untuk memenuhi syarat jumlah sampel yang dianjurkan dalam melakukan penelitian yang analisis datanya menggunakan 
teknik SEM dengan prosedur estimasi Maksimum Likelihood Estimation (MLE) yaitu 100 - 200 sampel.

Metode pengumpulan data yang akan penulis lakukan adalah dengan cara menyebarkan kuesioner secara langsung kepada responden. Teknik samplingnya penggunakan purposive sampling yaitu mengambil sampling dari dosen, staf administrasi dan mahasiswa yang merupakan informan key dalam penelitian ini.

Metode analisis data pada penelitian ini menggunakan teknik SEM dengan bantuan program SPSS Amos versi 19. Tahapan dalam penggunaan SEM yaitu membuat model, menentukan variabel, membuat path diagram, memilih data input dan estimasi model, mengidentifikasi model, mengevaluasi estimasi model, dan menguji kelayakan model.

Data primer yang diperoleh dari pengumpulan data diolah menggunakan program Excel terlebih dahulu, setelah itu data tersebut dianalisis dengan menggunakan tools SPSS AMOS versi 19.

\section{HASIL PENELITIAN}

Normalitas univariat dan multivariate terhadap data yang digunakan dalam data ini, diuji dengan menggunakan AMOS 19 . dengan menggunakan Critical Ratio (C.R), secara keseluruhan (multivariate) asumsi normalitas dapat terpenuhi, dimana angka-angka tersebut terletak pada rentangan nilai \pm 2.58 , yang berarti pada tingkat signifikansi $0,01(1 \%)$ dapat disimpulkan bahwa tidak ada bukti kalau data yang digunakan mempunyai sebaran yang tidak normal. Analisis Evalauasi outlier multivariate dilakukan dengan membandingkan jarak mahalanobis (mahalanobis distance) hasil pengolahan SEM dengan jarak mahalonobis hasil perhitungan manual. Perhitungan hasil pengolahan SEM terhadap jarak mahalanobis berdasarkan chi-square pada df : 224 (dengan p<0,005 memperoleh hasil sebesar 352,098. Sedangkan hasil pengolahan data menunjukkan nilai minimal mahalonobis sebesar 19,978 dan nilai maksimal sebesar 54,257 artinya < 352,098 sehingga dapat disimpulkan bahwa tidak terjadi outlier multivariate pada penelitian ini 
Tabel 1. Normalitas Data

Assessment of normality (Group number 1)

\begin{tabular}{|l|r|r|r|r|r|r|}
\hline Variable & Min & max & skew & c.r. & kurtosis & c.r. \\
\hline Puas & 1.000 & 5.000 & -.373 & -2.154 & -.460 & -1.327 \\
\hline Pakai & 1.000 & 5.000 & -.464 & -2.680 & -.361 & -1.041 \\
\hline Terima & 1.000 & 5.000 & -.525 & -3.031 & -.426 & -1.229 \\
\hline Add & 1.000 & 5.000 & -.427 & -2.463 & -.916 & -2.644 \\
\hline Motivasi & 1.000 & 5.000 & -.418 & -2.415 & -.857 & -2.473 \\
\hline Dukungan & 1.000 & 5.000 & -.481 & -2.778 & -.731 & -2.110 \\
\hline Ragu & 1.000 & 5.000 & -.266 & -2.584 & -.394 & -1.136 \\
\hline Menolak & 1.000 & 5.000 & -.187 & -2.782 & -.389 & -1.123 \\
\hline Menerima & 1.000 & 5.000 & -.609 & -3.519 & -.624 & -1.801 \\
\hline Efisien & 1.000 & 5.000 & -.590 & -3.408 & -.171 & -.493 \\
\hline Mudah & 1.000 & 5.000 & -.468 & -2.702 & -.143 & -.412 \\
\hline Butuh & 1.000 & 5.000 & -.359 & -2.074 & -.371 & -1.070 \\
\hline Efektif & 1.000 & 5.000 & -.451 & -2.604 & -.209 & -.605 \\
\hline Simple & 1.000 & 5.000 & -.123 & -3.707 & -.544 & -1.569 \\
\hline Paham & 1.000 & 5.000 & -.312 & -4.802 & -.541 & -1.562 \\
\hline Use & 1.000 & 5.000 & -.557 & -3.216 & -.310 & -.895 \\
\hline Interaksi & 1.000 & 5.000 & -.577 & -3.329 & -.284 & -.821 \\
\hline Kepentingan & 1.000 & 5.000 & .238 & 3.373 & -1.244 & -3.591 \\
\hline Minat & 1.000 & 5.000 & .151 & 2.874 & -1.252 & -3.613 \\
\hline Penguasaan & 1.000 & 5.000 & -.054 & -2.313 & -1.160 & -3.348 \\
\hline Sarana & 1.000 & 5.000 & -.240 & -3.388 & -1.304 & -3.765 \\
\hline Pelatihan & 1.000 & 5.000 & .116 & 3.670 & -1.361 & -3.928 \\
\hline reinforcement & 1.000 & 5.000 & -.087 & -3.504 & -1.296 & -3.740 \\
\hline Multivariate & & & & & 92.403 & 19.267 \\
\hline
\end{tabular}

Hasil pengujian untuk mengetahui kriteria Goodness of Fit dapat ditunjukkan seperti tabel 2 dibawah ini: 
Tabel 2

Hasil Evaluasi Kriteria Goodness of Fit Indices

\begin{tabular}{cccc}
\hline Keriteria & Hasil Model & Nilai Kritis & Evaluasi Model \\
\hline Chi Square & 364.543 & Diharapkankecil & Baik \\
Sig Probability & 0,173 & $\geq 0,05$ & Baik \\
CMIN/ DF & 1.620 & $\leq 2,0$ & Baik \\
GFI & 0,877 & $\leq 1,0$ & Baik \\
TLI & 0,928 & $\geq 0,90$ & Baik \\
CFI & 0,969 & $\geq 0,95$ & Baik \\
RMSEA & 0,056 & $\leq 0,08$ & Baik \\
\hline
\end{tabular}

Hasil evaluasi criteria goodness of fit indices pada table 5.6 menunjukkan bahwa model dinilai baik (fit) dan dapat diterima.

Dari hasil GOF menunjukkan bahwa model fit dan dapat diterima, maka uji validitas structural Model atau uji hipotesis dapat dilakukan dengan melihat nilai critical ratio..Kemudian setelah dilakukan uji hipotesis, terdapat 3 hubungan yang signifikan karena memiliki taraf signifikansi <0,05 yaitu Behavioral Intention to Use terhadap Actual System Use, Perceived Usefulness terhadap Behavioral Intention to Use dan Perceived Easy of Use terhadap Perceived Usefulness.

Tabel3

Regression Weights

\begin{tabular}{lllrrrrl}
\hline & & & Estimate & S.E. & C.R. & P & Label \\
\hline E & $<---$ & CSE & 7.244 & 12.575 & .576 & .565 & par_8 \\
E & $<---$ & OF & 2.020 & 9.443 & .214 & .831 & par_9 \\
\hline U & $<---$ & OF & .668 & 2.125 & .314 & .753 & par_13 \\
U & $<---$ & E & .635 & .205 & 3.100 & .002 & par_14 \\
A & $<---$ & U & 16.085 & 31.454 & .511 & .609 & par_17 \\
A & $<---$ & E & -10.580 & 21.107 & -.501 & .616 & par_18 \\
BI & $<---$ & A & -.076 & .155 & -.490 & .624 & par_21 \\
BI & $<---$ & U & 1.271 & .426 & 2.984 & .003 & par_25 \\
AU & $<---$ & BI & 1.242 & .338 & 3.676 & *** & par_24 \\
\hline
\end{tabular}




\section{DISKUSI}

Perceived Easy of Use memiliki pengaruh positif terhadap Perceived Usefulness

Pernyataan tersebut didukung oleh hasil uji struktural yang menghasilkan nilai C.R. pada regression weight yang identik dengan uji-t dalam regresi, terlihat angka C.R. $=3.100>1,645$ (menunjukkan bahwa variabel-variabel tersebut berhubungan secara signifikan). Dasar keputusan yang lain adalah dengan mengamati nilai probability $(\mathrm{P})$ yang dihasilkan yaitu $\mathrm{P}=0,002$ atau $\mathrm{P}<0,005$ yang berarti hipotesis diterima. Wahyudi, M. (2008) menganalisa faktor - faktor yang mempengaruhi penerimaan karyawan BSI terhadap Sistem Informasi Karyawan Berbasis Web dengan menggunakan pendekatan Technology Acceptance Model (TAM) dengan hasil bahwa faktor - faktor yang dominan dan saling berhubungan serta berpengaruh terhadap tingkat penerimaan teknologi, khususnya Sistem Informasi Karyawan Berbasis Webbagi karyawan kampus BSI adalah adanya persepsi kemudahan untuk menggunakan(Perceived Ease of Use), adanya persepsi manfaat menggunakan (Perceived Usefulness), adanya niat untukmenggunakan (Intention to Use) dan pengguna website itu sendiri (Website Usage).

Perceived Usefulness memiliki pengaruh positif terhadap Behavioral Intention to Use

Pernyataan tersebut didukung oleh hasil uji struktural yang menghasilkan nilai C.R. pada regression weight yang identik dengan uji-t dalam regresi, terlihat angka C.R. =2.984 -0.389 > 1,645 (menunjukkan bahwa variabel-variabel tersebut berhubungan secara signifikan). Dasar keputusan yang lain adalah dengan mengamati nilai probability $(\mathrm{P})$ yang dihasilkan yaitu $\mathrm{P}=0.003$ atau $\mathrm{P}<0,005$ yang berarti hipotesis diterima. Iqbaria et.al. (1997) menggunakan tiga buah konstruk untuk memeriksa pengaruhnya terhadap pilihan individu dalam menggunakan suatu komputer. Ketiga faktor ini adalah persepsi tentang kegunaan teknologi (perceived usefulness), persepsi tentang kesenangan (perceived enjoyment), dan faktor organisasi (internal dan eksternal organisasi). Dua indikator digunakan untuk memproksi penggunaan komputer mikro, yaitu 
penggunaan harian komputer mikro laporan-sendiri (self-reported daily use of micro-computers) dan frekuensi komputer mikro laporan-sendiri (self-reported frequency use of micro-computers). Hasil penelitian ini menunjukkan bahwa ketiga konstruk ini signifikan mempengaruhi penggunaan komputer mikro.

Behavioral Intention to Use mempunyai pengaruh positif terhadap Actual System Use

Pernyataan tersebut didukung oleh hasil uji struktural yang menghasilkan nilai C.R. pada regression weight yang identik dengan uji-t dalam regresi, terlihat angka C.R. $=3.676>1,645$ (menunjukkan bahwa variabel-variabel tersebut berhubungan secara signifikan). Dasar keputusan yang lain adalah dengan mengamati nilai probability $(\mathrm{P})$ yang dihasilkan yaitu $\mathrm{P}=0,000$ atau $\mathrm{P}<0,005$ yang berarti hipotesis diterima. Sejalan dengan penelitian Tangke, N. (2004) Penelitian ini berhasil membuktikan bahwa faktor yang mempengaruhi penerimaan penerapan TABK di BPK RI adalahpersepsi pengguna tentang kegunaan TABK dan secara tidak langsungoleh persepsi pengguna tentang kemudahan dalam menggunakan TABK. Penelitian ini juga membuktikan, faktor sikap pengguna terhadap penggunaan TABK tidak mempengaruhi keputusan auditor BPK RIuntuk menerima penerapan TABK dan sikap pengguna terhadap penggunaanTABK tidak dipengaruhi oleh persepsi pengguna tentangkegunaan TABK. Wibowo, A. (2006) menganalisa perilaku pengguna sistem informasi di sebuah institusi pendidikan tinggi berdasarkan faktor - faktor yang mempengaruhinya dengan pendekatan Technology Acceptance Model (TAM). Penelitian ini membuktikan bahwa tidak ada pengaruh antara persepsi tentang kemudahan penggunaan web (Perceived Ease of Use) dengan sikap penggunaan (Attitude Toward Using). Hal tersebut mengacu pada kenyataan bahwa pararesponden (mahasiswa) memang dituntut untuk mengakses web karena sebagianbesar fitur web, meliputi prosedur Kartu Rencana Studi (KRS), informasibimbingan tugas akhir, tugas-tugasperkuliahan, pemilihan kelompok dan berbagai fitur lainnya, harusdigunakan selama mereka studi. Dengandemikian mudah atau tidaknya webdigunakan tidak akan mempengaruhisikap responden terhadap penggunaanteknologi tersebut. 


\section{KESIMPULAN}

Model TAM cocok digunakan untuk mengetahui penerimaan dosen, mahasiswa dan staf akademik dalam menggunakan Sistem Informasi Akademik Stikes Harapan Bangsa. Hal ini diketahui berdasarkan nilai Chi Square (364.543), Sig Probability (0,173), CMIN/DF $(1,620)$, GFI $(0,877)$, TLI $(0,928)$, CFI $(0,969)$ dan RMSEA (0,056). Nilai - nilai tersebut berada dibawah nilai kritis yang ditetapkan yang berarti bahwa model fit / cocok dengan semua variabel yang diobservasikan. Pada penelitian ini diketahui bahwa terdapat 3 variabel dengan hubungan mempengaruhi dari 9 variabel. Variabel Perceived Easy of Use memiliki pengaruh positif terhadap Perceived Usefulness. Sementara itu terdapat 1 faktor yang berhubungan tidak langsung dengan penerimaan user di STIKES Harapan Bangsa yakni Perceived Usefulness, sedangkan Behavioral Intention to Use mempengaruhi secara langsung dari penerimaan dan penggunaan Sistem Akademik STIKES Harapan Bangsa.

\section{DAFTAR REFERENSI}

Alpar Paul and Kim Moshe. 1990. "A Micro economic Approach to The Measurement of Information Technology Value." Journal of Management Information System, pp. 55 - 56

Barua, A, Kriebel C.H. dan Mukhopadhayy, T.1995. "Information Technology and Business Value : An Analytic and Empirical Investigation." Information System Research, March 1995

Bertrand, M. and Bouchard, S., 2008, “Applying The Technology Acceptance Model to VR With People Who Are Favorable To Its Use", Journal of Cyber Therapy \& Rehabilitation Summber 2008, Volume 1, Issue 2.

Brynjolfsson, E. and Hitt. L.1996. "Paradox Lost? Firm Level Evidance on The Returns to Informations System."Management Science.

Burton Jones, A. and Straub. D. W. 2003. "Individual System Usage A Review of Theoris and Method."Working Paper, Georgia State University

Devaraj S. and Kohli.R. 2003. "Performance Impacts of Information Technology : Is Actual Usage The Missing Link ?.“Management Science. Pp. 273 289. 
Davis, F.D. 1989. "Perceived Usefulness, Perceived Ease of Use, and User Acceptance of Information Technology. MIS Quarterly, 13, 319-340.

Davis, F.D. 1989. "User Acceptance of Computer Technology : A Comparison of Two Theoretical Models". Management Science, Vol. 35 no. 8

Dennis F. Galletta, Yogesh Malhotra, 1993. Extending the Technology Acceptance Model to Account for Social Influence : Theoritical Bases and Empirical Validation Proceedings of the $32^{\text {nd }}$ Hawaii International Conference on System Sciences.

Fishbe M, Ajzen I. 1975. Belief, attitude, intentions and behavior: an introduction of theory and research. MA:Addison-Wesley.

Ghozali, I. 2008. Structural Equation Modeling Metode Alterantif Dengan Patrial Least Square.Edisi 2.Semarang : BP.Universitas Diponegoro.

Goodhue, D.L; Thompson, R.L, 1995."Task-Technology Fit and Individual Performance.” MIS Quarterly (19:2), pp.213-236

Igbaria M, Zinatelli N, Cragg P, Cavaye A. 1997. Personal computing acceptance factors in small firms: a structural equation model. MIS Q(3):279-302.

Jogiyanto, 2000. Sistem Informasi Berbasis Komputer. Yogyakarta : BPFE Yogyakarta

Jogiyanto, 2008. Sistem Informasi Keprilakuan. Yogyakarta: Penerbit Andi

Jr, Raymond McLeod and Schell George.2004.Sistem Informasi Management. 8 ed. Jakarta : PT INDEKS

Kurniawan, R, 2008. "Analisis Pengaruh Teknologi Informasi Pada Kinerja Organisasi Study Empiris PT. Bank Rakyat Indonesia (PERSERO) Tbk Unit Kantor Cabang Tegal, Kantor Wilayah Semarang.”, MAKSI UNDIP

Maharsi, Sri. 2004. Faktor-Faktor yang Mempengaruhi Minat Nasabah Menggunakan Internet Banking dengan Menggunakan Kerangka Technology Acceptance Model (TAM). http://puslit.petra.ac.id/journals/accounting/

Nasution, Fahmi Natigor. 2004. Penggunaan Teknologi Informasi Berdasarkan Aspek Perilaku (Behavioral Aspect). Digitized by USU digital library

Sunarta, I N, 2005. "Analisis Faktor-Faktor Yang Mempengaruhi Pemanfaatan Teknologi Informasi dan Pengaruh Pemanfaatan Teknologi Informasi Terhadap Kinerja Individual.”, MAKSI UNDIP 
Tangke, Natalia (2004) .Analisa Penerimaan Penerapan Teknik Audit Berbantuan Komputer (TABK) dengan Menggunakan Technology Acceptance Model (TAM) pada Badan Pemeriksa Keuangan (BPK) RI, Jurnal Akuntansi \& Keuangan, $6 \quad$ (1),10 - 28.Mei, 2004.http://puslit.petra.ac.id/journals/accounting/

Wahyudi, Mochamad, 2008. Kajian Penerapan Sistem Informasi Karyawan Berbasis Web Berdasarkan Pendekatan TAM. Http://www.wahyudi.or.id/

Wibowo, Arief, 2006. Kajian Penerapan Sistem Informasi Akademik Berbasis Web Berdasarkan Pendekatan TAM : Studi Kasus di Universitas Budi Luhur, Tesis, Jakarta : Universitas Budi Luhur 